\title{
Corporate Governance as a Strategic Management Tool
}

\author{
Olatunji, Toyin Emmanuel Ph.D \\ Department of Accounting, LadokeAkintola University of Technology Ogbomoso, Oyo state Nigeria \\ Adeleke, Mary Toyin \\ Department of Accountancy, Federal Polytechnic, Ado-Ekiti, P. M. B. 5351, Ekiti State, Nigeria
}

\begin{abstract}
The objective of the study is to determine the effectiveness of corporate governance as a strategic tool in improving performance of listed manufacturing company in Nigeria. The specific objective is to examine the relationship between corporate governance mechanisms and performance of manufacturing firms in Nigeria. This study adopted quantitative research; the population for the study is seventy four, which is the total number of listed manufacturing companies in Nigeria. Twenty manufacturing companies were purposively selected from the seventy four manufacturing companies listed on the Nigeria stock exchange that formed the population of the study. The study is based on content analysis of the selected firms' annual reports for ten years, from year 20082017. Time series data were collected to determine corporate governance and profitability performance of the selected companies. Five (5) aspects of corporate governance were investigated; these include board size, gender, independence, meeting and audit committee size. The data collected were analyzed using panel data analysis. Findings revealed that heterogeneity effect across firms and over time are incorporated into the model via the error term, Board Size (BOS) and Board Gender Disparity (BGD) had negative impact on the financial performance of manufacturing firms in Nigeria. It is recommended that organizations should use corporate governance as a strategic tool to achieve corporate objectives especially by ensuring the board meets regularly to monitor and control.
\end{abstract}

Keywords: Audit Committee Size, Board Gender Disparity, Board Independence, Board Meeting, Board Size, Corporate Governance, Corporate Performance, Strategic Management

DOI: $10.7176 / \mathrm{RJFA} / 10-14-11$

Publication date:July $31^{\text {st }} 2019$

\subsection{Introduction}

Strategic management specifies the mission, vision and objectivesof organizations; involves the design of polices and plans, project and programs to achieve objectives; and allocates resources to implement polices plans, projects and programs. Strategic management can help the organization to operate successfully in a complex or dynamic environment by becoming more flexible (Hossein \& Fatemeh, 2012). Corporate governance, on the other hand, can provide a system by which the goals and objectives of organization are set and accomplished. Strategic failure can be avoided if managers and the board observe and correct the mistake quickly. Corporate governance should provide checks, balances, and incentives to spot, correct bad decisions and if corporate governance is strengthened, companies can strengthen their strategies and their ability to compete.

Strategic management is a continuous process that matches the organization with its changing environment in the most advantageous possible way (Pearce\& Robinson, 2007). Strategic management uses different strategies to become successful and remain successful. They are set of decisions and actions that can be taken to achieve corporate objectives by developing effective's strategies. Strategies are plans or decisions put in place to achieve set of objectives of an organization. Corporate governance is a strategic management tool for achieving business goals and objectives. (Arganti \& Druck, 2004).Weak corporate governance can lead to weak organization strategy and thus, the strategic position and success of an organization depends on good corporate governance. 
Corporate governance is the set of processes, customs, policies, laws and institutions that affect the way in which companies are directed and controlled (OECD, 2010). Good corporate governance lead to more profit making, sales and increased valuation and lower capital expenditure. Corporate governance is a strategic tool that most companies use to improve their performance and production, operations, marketing, strategy, financial plans, product development, human resource management, expansion strategy and procurement procedures.(Karanju,2015).Corporate governance depends largely on the board size, independent directors, CEO selection and board diversity.Good governance should provide the board and management incentive that will enable them achieve the objectives in the interest of the company as a whole and it will enable shareholders to able to monitor effectively (Odiwo, Chukwuma \& Kifordu, 2016). Autchinson, (2012), added that the board of directors as strategic resource can give firm access to fund, skills, methods and opportunity.

Several researches have been carried out in the financial sector on the effect of corporate governance on performance but few researches have been carried out in the manufacturing sector in Nigeria. In Botswana, Sathyamoorthi, Pritika, Mashoko and Lilian(2017) agreed that there is significant impact, In India Palaniappan, (2017)indicated that there is a significant negative relationship between corporate governance and performance. Other researches in Nigeria included Nwiko, Florence and Ileko (2018), Nwiwu and Joseph (2018)their findings indicate that audit committee members have a significant effect on earnings per share and return on assets while board size does not significantly relate to return on assets of organization. Geraldine, Sunday and John (2017) discovered that board size, board composition, audit committee size had significant effect on capital employed. Oyedokun, Sanyaolu and Bamidele (2017) established that corporate governance variables of interest had significant effect on performance of listed firms in Nigeria. Osundina, Olayinka, and Chukwuma (2016), revealed that the performance indicator ROA related with each component of the corporate governance. Odiwo, Chukwuma and Kifordy (2016), the findings reveals that CEO shareholding has a positive and significant impact on organization performance but Director's shareholding has a negative and significant impact on the organization performance.

The findings are not consistent; some researchers agreed that there is a negative relationship while some agreed that there is a positive relationship between the variables of corporate governance and financial indicators. Different methods of analyses were conducted on the data, but this research used panel data analysis to find out if the findings also hold for the manufacturing industry in Nigeria. Different corporate governance mechanisms were used by different researchers but this research considered board size, board meeting, Audit committee size, board independence and board gender disparity.

The objective of the study is to determine the effectiveness of corporate governance as a strategic tool in improving performance of listed manufacturing company in Nigeria. The specific objective is to examine the relationship between corporate governance mechanism and ROA; to assess corporate governance practice in selected manufacturing company; and, to examine the effect of board size, board meetings, audit committee size, board independence and gender sensitivity of the board members on the performance of manufacturing firms in Nigeria.

\subsection{Literature Review}

\subsubsection{Corporate Governance and Strategic Management}

Strategic management can help the organization to operate successfully in a complex or dynamic environment by becoming more flexible (Hossein \& Fatemeh, 2012). Corporate governance provides a system by which the goals 
and objectives of organizations are set and accomplished. Strategic failure can be avoided if management and board observe and correct their mistakes quickly. Corporate governance should provide checks, balances, incentives to spot, correct bad decisions and if corporate governance are strengthened organizations can strengthen their strategies and their ability to compete (Zeyad, Atif \& Hazem, 2015).

\subsubsection{Code of Corporate Governance in Nigeria}

The crisis of Lever Brothers in the 1990's made Security and Exchange Commission (SEC) to draw up its own code of corporate governance for 2003. It was later reviewed and made compulsory for every quoted company to follow and implement in 2014.Financial Reporting Council of Nigeria Act, (2011) empowered Financial Reporting Council to supervise and monitor all relevant issues that affect corporate governance in Nigeria. The council also developed principles and practices of good corporate governance in Nigeria and has issued a National code of corporate governance in 2016 which is mandatory for public sector, private sector and not for profit making organization.

SEC code of corporate governance state that the board is accountable and responsible for the performance and the affairs of the company and also to ensure sound corporate governance in the company. The duties of the board include formulation of policies and overseeing the effectiveness and adequacy of internal control system.

Company and Allied Matters Act, 2004 said the director is any person occupying the position of directors by whatever name called. Two types of directors include executive and non-executive directors.

\subsubsection{Board size}

The board size means the number of directors sitting on the board. SEC code specify that the member of the board should not be less than five, there must be a mixture of both the executive and non-executive director majority should be non-executive and at least there must be an independent director. The role of non-executive director include monitoring executive activities and to contribute to strategic development. In Odiwo, Chukwuma and Kifordu (2016), Brown and Caylor (2014) opined that ideal board size should be between 6-15 members to enhance the effective performance of the board.

\subsubsection{Board Meeting}

This is the number of times which the member of the board must meet according to SEC code of corporate governance; the board members are to meet at least once every quarter. For the board to have full control and monitor the executive they must meet regularly (Odiwo, Chukwuma \& Kifordu, 2016).

\subsubsection{Board Independence}

The SEC code state that the board should be independent of management to enable it carries out its oversight function in an objective and effective manner.

\subsubsection{Audit Committee Size}

CAMA (2004) provide that auditors should make a report to an audit committee. The audit committee shall consist of an equal number of directors to a maximum of six members they are to examine the auditor's report and also make recommendation thereon to the annual general meeting.

\subsubsection{Board Gender Disparity}

When diverse groups are well represented on the board it will prevent an individual from dominating the decision process on the board (Nielsen \& Huse, 2010). More women on the board might likely lead to increase in firm performance. 


\subsubsection{Corporate Performance}

Corporate performance is the way in which the financial resources are used to achieve the objectives of the organization (Nworji,2011). Performance can be measured from different angle such as financial performance, product market performance and shareholder's return. Financial performance can be measured using return on assets, return on investment (Owolabi, 2018). Researchers like Nwaiwu \& Joseph (2018), Sathyamoorthi, Pritika, Mashoko \& Lilian (2017) have used return on assets (ROA) index in measuring performance.

\subsubsection{Benefit of good corporate governance}

Karanja (2015) reported that good corporate governance is a strategic tool that can be used to achieve set goals and objectives and it can positively affect production, operations, marketing strategy, financial planning and budgeting, product development, human resource management, expansion strategy, and procurement procedures. Moreover, it improves efficiency in the operations of the company, reduce costs, and hence increase profits and general performance and profitability if complied with, institutionalized and well integrated into their corporate plans. It can also result in retention and attraction of competent human resource, better marketing strategies, efficient operations and production, improved financial planning and budgeting, superior product development, successful expansion strategies and effective and efficient procurement procedures.

Owolabi (2018), noted that the essence of good corporate governance is to assess whether the performance are in line with plans and to motivate participants to align with their various activities, actions and inactions with the overall objectives of the organizations. It also induces the accountability of those who are in management positions which also serve as increase in wealth creation. Corporate governance enhances credibility and attracts global investors to show interest and confidence in the organization. Corporate governance places an organization on a very high competitive status, encourage transparency, and stimulate effective communication required by the stakeholders. It also helps to develop business sustainability, macro-economic stability, and attract development assistance to achieve sound reputation

\subsubsection{Problems of Corporate Governance in Nigeria}

Failure of corporate governance can be as a result of some problems. Weak and inadequate enforcement capacity of Company and Allied Matters Act (CAMA). Some board members who have no finance and business operating ability are been selected from highly placed retired military officers and civil servants. Some of the executive members collaborate with the senior executives of the companies to satisfy their personal interest as the business and shareholders interest is secondary to their interest. At times annual general meetings are located at places that are not easily accessible by most shareholders thereby preventing them from getting involved in the governance issues. Some executives are not been checked regularly and this gives them room to engage in gross misconduct because some investors are not included in governing structure. Inadequate executive member training and capacity development to manage business has resulted high agency cost and loss of profit (Owolabi, 2018).

Weak corporate governance system in Nigeria has led to collapse of textile industry in Nigeria thereby leading to huge loss to economy of Nigeria as a whole. It has led to banking crisis, many banks have collapsed in the past, and other industries have been affected in the past such as Erisco Food Ltd. in Oregun-Lagos, Dunlop and Michelin companies, Cadbury. If the corporate governance system is effective many of the crises in the manufacturing industry would have been prevented and the industry would have enlarged (Owolabi, 2018). 
Expectations gaps exist around boards of director. Expectation gap is the difference in opinion that exists between two or more people. Expectation gap can be reasonableness gap or performance gap. There exist expectation gap between what stakeholders expect and what the boards can actually contribute and this can be a problem. Performance expectation gap include ability to fire the CEO, monitoring could be difficult in practice, board may not be able to control daily, the board may not be independent and information asymmetry among managers may conceal accurate and timely information from the board members. Reasonableness expectation gap include, lack of agreement on the role and duties that the board are to play. Their role may be conflicting at times by over trusting the management when they are performing and managers may take liberties and do what they like. Other reasonableness gap include negative impact that some role of board on company performance. The role that the board may play can be restricted and the directors have limited ability to monitor and control the managers (Niamh, 2006).

\subsubsection{Conceptual framework of Corporate Governance as a Strategic Management Tool}

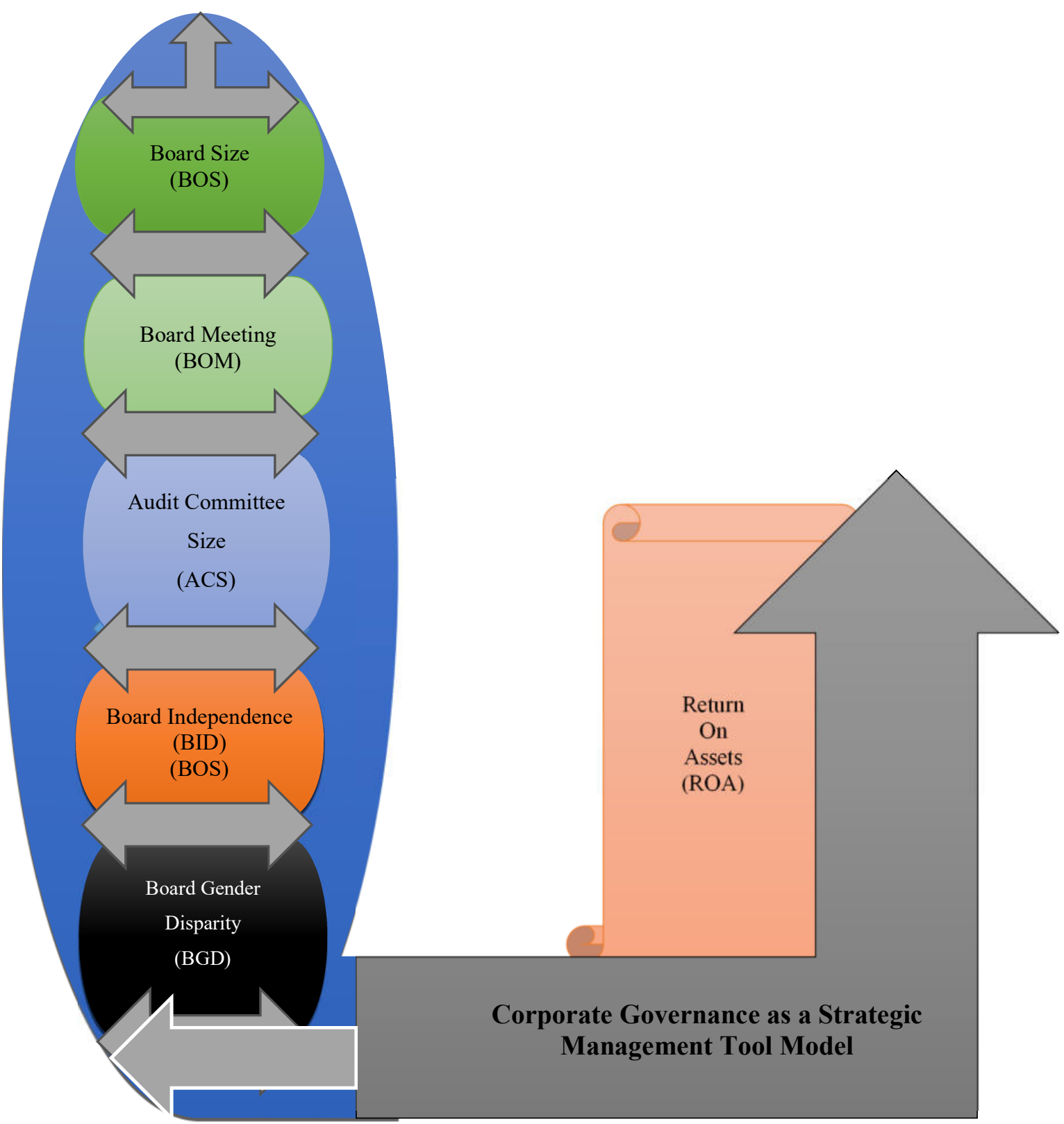




\subsection{Theoretical Review}

\subsubsection{Agency Theory}

Agency theory was originally developed by Jensen \& Meckling (1976). Agency problems arise when investors have difficulties in monitoring the funds provided to managers. The agents maximize their own interest at the expense of investors. The origin of agency problem emerged from separation of ownership and control, where the principal contracts the agent to act on his behalf. The agents are the management and board of directors of the companies entrusted with maximizing shareholder wealth. Hasan and Halbouni, (2013) Stated that corporate governance is a mechanism used in solving agency problem. The principals can adopt corporate governance to monitor the agent. Effective corporate governance can improve performance and financial results of companies. Corporate governance can be put in an organization to disclose, monitor, align the objectives of principals and the agent and also minimize agency cost.

\subsubsection{Resource Dependency Theory}

This was propounded by Jeffrey and Gerald (1970). Board of directors can use their oversight function to manage the resources of the organization. Resources are the keys to organizational success and access to control over resources is a basis of power. External resources of the organization can affect the behavior of the organization. The external resource is an important tenet of both the strategic and tactical management (Amy, Micheal \& Brian, 2009). Board size has the ability to provide resources that organization need. Board size is rational organization and can respond to the situation of external environment. It was further stated in Pearce and Zahra (1992), that board size and board composition are contingent on the firm's current strategy and prior financial performances. Advantages of having directors in an organization's can make the organization to have access to channels of information between the organization and the environmental contingencies. They can give advice and counsel; they can get access to resources and legitimacy. According to this theory the board is a strategic tool which can connect the various external resources in an organization (Ingley \& Vander, 2001).

Pfeffer and Salancik (1978) noted that Board of Directors can be a mechanism that interacts with the environment and accessing the resources in the environment. The environment where the organization and board of directors are located matters and it has effect. The environment may affect how the board of directors affect the performance of the organization and only way to overcome that is to have an appropriate board composition on board of directors.

\subsection{Empirical Review}

In Kenya, Karanja (2015) carried out a study on the effect of corporate governance as a tool to improve performance of listed companies in Kenya. Both questionnaire and data extracted from the audited financial statement were used. The findings showed that most of the companies listed at the Nairobi Securities Exchange were implementing corporate governance guidelines issued by the Capital Markets Authority and had incorporated corporate governance practices into their corporate strategies resulting to improved performance and had discovered that corporate governance was an effective strategic tool to improve performance of listed companies in Kenya.

In Botswana, Sathyamoorthi, Pritika, Mashoko and Lilian(2017) focused on six listed consumer services companies for a period of 2012 to2016 to examine the effect of corporate governance on financial performance of organization. Return on assets was the dependent variable used in measuring profitability while board size, gender 
diversity, (male-female representation in the board), composition of executive and non-executive directorship, number of sub-committees, and frequency of board meetings as independent variables. From the research, there was a significant positive relationship between board size and the number of male board members and between board size and the number on non-executive directors. The number of sub-committee also had significant impact on the financial performance of the listed companies.

In India Palaniappan, (2017)examined the impact of board characteristics such as board size, CEO duality, independence and board activities on the financial performance of manufacturing firms in India. Data were drawn from 275 firms listed in NSE from the period of 2011-2015 using multiple regression models. The findings indicate that there is a significant negative relationship between board characteristics such as board size, board independence and board meetings with firm's performance indicators of ROE. In Iran, Hossein and Fatemeh (2012), investigated the relationships between corporate governance, organizational learning and strategic planning effectiveness. The researcher used questionnaire to gather the data which was analyzed using regression analysis to analyse the data and concluded that corporate governance and non-organizational learning is significantly associated with strategic planning effectiveness. Both corporate governance and organizational learning facilitate the effectiveness of strategic planning.

Nwiko, Florence and Ileko (2018), investigated the effect corporate governance has on the performance of aluminum manufacturing companies in south-south, Nigeria. The study used survey approach and covered a population of 305 management staff of 25 selected Aluminum manufacturing firms from six states of South-South region of Nigeria. Judgmental sampling technique was used. It was recommended that the cost of maintaining corporate governance structures in the organization should be controlled in order to ensure that it does not negate the cost efficiency goals of the organization. There is need to give orientation on the principles of corporate governance to the owners, employers and employees of medium scale manufacturing firms.

Nwiwu and Joseph (2018), investigated relationship between core corporate governance and financial performance of quoted manufacturing companies in Nigeria. Time series data were collected from 2012 to 2016 annual report of 10 selected companies. It was analyzed using ordinary least square of multiple regressions. The findings indicate that audit committee membership had significant effect on earnings per share and return on assets while board size does not significantly relate to return on assets of organization. Geraldine, Sunday and John (2017), carried out a study on corporate governance and organizational performance focusing on annual report of manufacturing industry in Nigeria. Ordinary least square regression technique was used to analyze the data. It was discovered that board size, board composition, audit committee size have significant effect on capital employed.

Oyedokun, Sanyaolu and Bamidele (2017), investigated the effect of corporate governance mechanism on firms' performance from the perspective of shareholders wealth maximization in Nigeria. It analyzed the annual reports of 10 selected companies for 10 years from 2007 - 2016 by employing the use of multiple regression technique. The finding established that corporate governance variables of interest have significant effect on performance of listed firms in Nigeria

Osundina, Olayinka, and Chukwuma (2016), investigated the relationship between corporate governance measured by board structure index, ownership structure index and audit committee and performance measured by Return on assets of selected Nigeria Manufacturing companies. The study adopted ex-post factor research design. Random sampling was used to select 30 companies out of 45 manufacturing companies listed on the Nigeria stock exchange 
for a time period of 2010 to 2014, multiple regression analysis and descriptive statistics were used in analyzing the data. It revealed that the performance indicator ROA related with each component of the corporate governance. It is therefore suggested that reform efforts should be directed towards improving the corporate governance of listed Nigeria manufacturing companies especially emphasis should be devoted to the variables of ownership structure and audit committee.

Odiwo, Chukwuma and Kifordu (2016), examined the impact of corporate governance on performance of manufacturing firms in Nigeria. They used the audited annual financial statement of 30 manufacturing company in Nigeria from the period of 2010 to 2014, which was analyzed with correlation and, heteroskedasticity test was carried out with regression analysis. The findings revealed that CEO shareholding has a positive and significant impact on organization performance but Director's shareholding has a negative and significant impact on the organization performance.

The main gap in these empirical tests conducted in Nigeria has to do with the limited number of years covered by the data used for regression analysis. The findings would have been more robust and revealing if the panel data were employed for the analysis. This was considered in this study.

\subsection{Methodology}

This study adopted quantitative research design because it enables the researcher to generalize the findings of a study to a larger population. The population of the study is seventy four, which is the total number of listed manufacturing companies in Nigeria. Twenty manufacturing companies were purposively selected from the seventy four manufacturing companies listed on the Nigeria Stock Exchange that formed the population of the study. The study is based on content analysis of the selected firm's annual reports, whereby data were extracted from ten years audited financial statement of the selected companies from 2006 t0 2017. Time series data were collected to determine the corporate governance and the profitability performance of the selected companies, the five aspect of the corporate governance were examined in line with the provision of corporate governance for companies; these include board size, gender, independence, meeting and audit committee size. The data collected is analyzed using panel data analysis.

\section{Model specification}

The fixed effect model is given thus:

$$
Y_{i t}=a_{0}+\beta_{1} X_{i t}+\delta i+\mu_{i t}
$$

$\delta i$ is a time varying intercept that captures all the variables that affect $Y_{i t}$ that very over time but are constant cross-sectionally. In substituting the variables under consideration into the fixed effect model, it will appear thus:

$$
R O A_{i t}=a_{0}+\beta_{1} B O S_{i t}+\beta_{2} B O M_{i t}+\beta_{3} A C S_{i t}+\beta_{2} B I D_{i t}+\beta_{3} B G D_{i t}+\delta i+\mu_{i t}
$$

Where ROA is Return on Assets, BOS is Board Size, BOM is Board Meeting, ACS is Audit Committee Size, BID is Board Independence, and BGD is Board Gender disparity. The random effect model follows the forms presented below:

$$
Y_{i t}=a_{0}+\beta_{1} X_{i t}+W_{i t}, W_{i t}=€_{i t}+\mu_{i t}
$$


Where $€_{i t}$ measures the random deviation from the global intercept a, subscript "it" represents the combination of time and individuality. $\mathrm{U}_{\mathrm{it}}$ means error term. In substituting the variables under consideration into the fixed effect model, it will appear thus:

$$
R O A_{i t}=a_{0}+\beta_{1} B O S_{i t}+\beta_{2} B O M_{i t}+\beta_{3} A C S_{i t}+\beta_{2} B I D_{i t}+\beta_{3} B G D_{i t}\left(\varepsilon_{i t}+\mu_{i t}\right)
$$

The selection of the best suited model from the two is done following the Hausman test

\subsection{Results and Discussion}

\subsection{Results}

\section{Descriptive Statistics}

Table 1 provides summary statistics for the pooled data of the sampled manufacturing firms for 12 years, spanning from 2006 to 2017. As revealed on the table, ROA of the sampled manufacturing firm have a mean value of 5.9185 with a mild degree of volatility of 9.4915. It was ranged from a minimum value of 0.1766 to a maximum value of 34.9119. The implication of this discovery is that for every one naira invested, the industry made a loss of $\$ 176,600$ million and made a maximum gain of $\$ 34.912$ million. The average values for BOS and ACS were 4.8739 and 1.4701 respectively alongside their standard deviation values reported to be 1.4701 and 0.880 . While their minimum values were 4 and 2, the maximum values were 18 and 19. This implies that the average number of members of a board of any manufacturing firms in Nigeria is 10 members, minimum is 4 and the maximum is 18. For BOM, members of the board meet 5 times in a year, with a minimum time of 2 and a maximum time of 19. Mean and standard deviation values of ACS were 5.5443 and 0.8800 , ranged from a minimum value of 5 and a maximum of 7. The average and standard deviation values of BID reported were 0.6218 and 0.1443 respectively, ranged from the minimum value of 0 to a maximum value of 0.92 . In the same vein, the average and standard deviation values of BGD reported were 0.0855 and 0.0955 respectively, ranged from the minimum value of 0 to a maximum value of 0.40 . Statistics presented above described each of the variables as pooled over 20 manufacturing firms in Nigeria.

Table 1: Descriptive Statistics

\begin{tabular}{|l|l|l|l|l|l|l|}
\hline & ROA & BOS & BOM & ACS & BID & BGD \\
\hline Mean & 5.9185 & 9.4915 & 4.8739 & 5.5443 & 0.6218 & 0.0855 \\
\hline Std. Dev. & 5.2287 & 2.7556 & 1.4701 & 0.8800 & 0.1443 & 0.0955 \\
\hline Minimum & 0.1766 & 4 & 2 & 3 & 0.00 & 0.00 \\
\hline Maximum & 34.9119 & 18 & 19 & 7 & 0.92 & 0.40 \\
\hline
\end{tabular}

Source: Authors' Computation

Where ROA is Return on Assets, BOS is Board Size, BOM is Board Meeting, ACS is Audit Committee Size, BID is Board Independence, and BGD is Board Gender disparity

\section{Correlation:}

Result presented in Table 2 showed that there was a positive relationship between ROA and BOS (0.4775), BOM (0.4021), ACS (0.0872), BID (0.2185) and a negative relationship with BGD (0.2115). This indicated that increase 
in the BOS, BOM, ACS and BID engendered increase in ROA of manufacturing firms in Nigeria. In the same vein, it was equally gathered from the Table that there was a negative relationship between ROA and BGD of the manufacturing firm in Nigeria showing that ROA and BGD moved in the opposite direction for the period covered by this study for manufacturing firms in Nigeria.

Table 2: Correlation Matrix

\begin{tabular}{|l|l|l|l|l|l|l|}
\hline & ROA & BOS & BOM & ACS & BID & BGD \\
\hline ROA & 1 & & & & & \\
\hline BOS & 0.4775 & 1 & & & & \\
\hline BOM & 0.4021 & 0.2651 & 1 & & & \\
\hline ACS & 0.0872 & 0.3611 & 0.1645 & 1 & & \\
\hline BID & 0.2185 & -0.0456 & 0.3497 & 0.0204 & 1 & \\
\hline BGD & -0.2115 & 0.1002 & 0.1992 & 0.0944 & -0.1797 & \\
\hline
\end{tabular}

Source: Authors Computation

\section{Panel Data}

\section{Fixed Effect Model}

Result of fixed effect estimation presented in Table 3 showed that when heterogeneity effect over time is incorporated into the model as intercept term, Board Size (BOS) and Board Gender (BGD) exert a negative impact on the financial performance of manufacturing firms in Nigeria measured in terms of ROA. The impact is only significant for BOS $(r=-0.5301, p<0.05)$, while for $B G D(r=-0.2975, p>0.05)$ and thus is not significant. Consequently, Board Meetings (BOM), Audit Committee Size (ACS) and Board Independence (BID) exert positive impact on the performance of manufacturing firms in Nigeria measured in terms of ROA for the period covered by this study. The impact is only significant for BOM $(r=0.5786, p<0.05)$, while ACS and BID had $r$ $=0.5018, \mathrm{p}>0.05$; and, $\mathrm{r}=0.6263, \mathrm{p}>0.05)$ respectively. R-square value reported for the whole is 0.5901 , which implies that about $59 \%$ of the systematic variation in ROA can be jointly explained by the explanatory variables (BOS, BOM, ACS, BID and BGD).

Table 3: Fixed Effect Model

Dependent Variable: ROA

\begin{tabular}{|l|l|l|l|l|}
\hline Variable & Coefficient & Std Error & t-statistics & Prob. \\
\hline C & 32.0604 & 10.8650 & 5.72 & 0.013 \\
\hline BOS & -0.5301 & 0.1387 & 2.89 & 0.003 \\
\hline BOM & 0.5786 & 0.2562 & 2.58 & 0.020 \\
\hline ACS & 0.5018 & 0.4241 & 1.18 & 0.240 \\
\hline BID & 0.6263 & 2.5376 & 0.25 & 0.805 \\
\hline BGD & -2.2975 & 3.9142 & 0.59 & 0.558 \\
\hline
\end{tabular}

Source: Authors' Computation

R-Squared $=0.5901$

F-statistics $=17.783$ 
$\operatorname{Prob}($ F-statistics $)=0.000$

\section{Random Effect Model}

Random Effect estimation result presented above revealed that when heterogeneity effect across firms and over time is incorporated into the model via the error term, Board Size (BOS) and Board Gender (BGD) had negative impact on the financial performance of manufacturing firms in Nigeria measured in terms of ROA. However, BOS has significant impact on ROA ( $r=-0.4442$, $p<0.05$ ), while for BGD, $r=-0.9173, p>0.05)$. BOM on the other hand had a positive impact on ROA of manufacturing firms in Nigeria $(r=0.3583, p<0.05)$. Audit Committee Size (ACS) and Board Independence (BID) both had positive but non-significant effects on the ROA of the manufacturing Firms in Nigeria $(r=0.4714, \mathrm{p}>0.05$; and, $\mathrm{r}=0.5391, \mathrm{p}>0.607)$ respectively. R-square value reported for the estimation stood at 0.5340 , which reflect that about 53.4 per cent of the systematic variation in ROA can be jointly explained by the explanatory variables (BOS, BOM, ACS, BID and BGD).

\section{Table 4: Random Effect Model}

Dependent Variable: ROA

\begin{tabular}{|l|l|l|l|l|}
\hline Variable & Coefficient & Std Error & t-statistics & Prob. \\
\hline C & 24.6557 & 5.7699 & 3.60 & 0.0021 \\
\hline BOS & -0.4442 & 0.1368 & 2.60 & 0.012 \\
\hline BOM & 0.3584 & 0.1442 & 2.34 & 0.022 \\
\hline ACS & 0.4714 & 0.4182 & 1.13 & 0.260 \\
\hline BID & 0.5391 & 2.4034 & 0.22 & 0.823 \\
\hline BGD & -0.9173 & 3.7231 & 0.51 & 0.607 \\
\hline
\end{tabular}

Source: Authors' Computation

R-Squared $=0.5340$

Wald Chi 2(3) $=18.29$

Prob $>$ Chi $2=0.001$

\section{Hausman Test}

Table 5 reported a chi-square statistic of 3.36 and the probability value of 0.0644 . The result revealed that there was not enough evidence to reject the null hypothesis that differences in coefficients of fixed effect estimation and random effect estimation were not significant. Therefore, the most consistent and efficient estimation was given by the random effect estimation as presented in Table 4. It thus becomes evident that the estimation that best explained the impact of corporate governance on the performance of manufacturing firms was Board Size (BOS) and Board Gender (BGD) exerted a negative impact on the financial performance of manufacturing firms in Nigeria measured in terms of ROA, though the impact is only significant for BOS $(r=-0.4442, p<0.05)$, while for $\operatorname{BGD}(\mathrm{r}=-0.9173, \mathrm{p}>0.05)$. Consequently, Board Meetings (BOM) exerted a positive impact on the ROA of manufacturing firms in Nigeria $(r=0.3583, \mathrm{p}<0.05)$. Audit Committee Size (ACS) and board Independence (BID) exerted a positive but non-significant effect on the ROA of manufacturing firms in Nigeria $(r=0.4714, p>0.05$; and $r=0.5391, p>0.607$ ) respectively.

\section{Table 5: Hausman Test}

\begin{tabular}{|l|l|c|}
\hline Null hypothesis & Chi-square stat & Probability \\
\hline The difference in coefficient not systematic & 3.36 & 0.0644 \\
\hline
\end{tabular}

Source: Authors' Computation 


\subsection{Discussion of Findings}

An attempt has been made to show the effect of corporate governance on the performance of manufacturing firms

in Nigeria. Mechanisms of corporate governance used were board size, board meetings, audit committee size, board independence and gender sensitivity of the board members. Data gathered from 20 quoted manufacturing firms were analyzed using descriptive statistics of mean, standard deviation, minimum and maximum, followed correlation matrix that shows the direction of the relationship between the explained and explanatory variables after which the study used a random effect model and fixed effect model of panel data regression. Through, Hausman test, it was gathered that the estimation that best explains the impact of corporate governance on the performance of manufacturing firms is the random effect estimation presented in Table 4.

The first discovery was that board size has a negative and significant effect on the profitability of manufacturing firms in Nigeria measured using return on assets. This implies that roles of the members of the board in improving the monitoring functions, improve governance and increase returns have been negatively affecting the performance of firms in terms of return on assets. This outcome gave credence to the findings of Ajala, Amuda, and Arulogun (2012), that there was a negative but significant relationship between board size and the performance of banks in Nigeria. It was equally gathered that board meeting had positive effect on return on assets of the sampled manufacturing firms in Nigeria, showing that increased number of meetings might lead to enhanced performance of manufacturing firms in Nigeria. Intermittent meetings of members of the board could engender good governance.

In the same vein, it was gathered that the impact of audit committee size and board independence on the return on assets of the manufacturing firms was positive but insignificant. This implies that the size of the audit committee and the independence of the board members have not contributed to the performance of the manufacturing firms in Nigeria meaningfully. The positive relationship between the board composition and the performance could be explained by the objective view of the non-executive directors regarding the company. Therefore, they are more suitable to accomplish the supervisory function. While the non-significant relationship is consistent with the regulatory requirement in manufacturing sector that director do not emphasize value maximization over the soundness and the safety of the firm. This outcome gave credence to the findings Osundina, Olayinka, and Chukwuma(2016), that the performance indicator ROA related with each component of the corporate governance such as audit committee size.

Another discovery made was that gender of the members of the board had negative but non-significant impact on return on assets of the manufacturing firms in Nigeria. This implies that the performance of these firms is not gender-sensitive. This appears to negate the general belief that the presence of the female on the board of directors has a crucial role in increasing board's independence since women tend to ask different questions than male directors. Moreover, female directors are considered as hard-working person and have better communication skills which enable them to add value in the firm by improving the decision-making ability and the problem solving of the board. This outcome failed to corroborate the discovery of Sathyamoorthi, Pritika, Mashoko and Lilian (2017), that gender of the board member positively influences the performance of firms. 


\subsection{Conclusion}

From the results of the analysis the board size had a negative and significant effect on the profitability of manufacturing firms in Nigeria. This implies that roles of the members of the board in improving the monitoring functions, improve governance and increase returns had negative effect on the performance of firms. It was also noted that board meeting had positive effect on ROA of the sampled manufacturing firms in Nigeria, it was concluded that increase in the number of meetings might lead to enhanced performance. The size of the audit committee and the independence of the board members have not contributed to the performance of the manufacturing firms in Nigeria meaningfully. The positive relationship between the board composition and the performance could be explained by the objective view of the non-executive directors regarding the company. Therefore, they are more suitable to accomplish the supervisory function.

Another discovery made was that gender of the members of the board had negative but non-significant effect on performance of the manufacturing firms in Nigeria. This negated the general belief that the presence of the female on the board of directors has a crucial role in increasing board's independence since women tend to ask different questions than male directors. Moreover, female directors are considered as hard-working and possessing better communication skills which enable them to add value in the firm by improving the decision-making ability and the problem solving of the board.

It is recommended that organizations should employ corporate governance as a strategic tool to achieve corporate objectives. The board must meet regularly to be able to monitor and control. Strategic failure can be avoided if managers and the board meet regularly to observe and correct the mistakes quickly enough. Corporate governance should be strengthening so that organizations' can strengthen their strategies and their ability to survive in a competing environment.

\section{References}

Ajala, O. A., Amudu, T. \& Arulogun, L. (2012). Evaluating The Effects Of Corporate Governance On The Performance of Nigerian Banking Sector. Review of Contemporary Business Research, 1(1), 32-42

Amy, J. H., Michealm C. W., \& Brian, J. C. (2009). Resource dependency theory: A Review Journal of Management, 35(6): 1404-1427

Argenti, P. \& Druck, B. (2004). Reputation and the control brand. Corporate Reputation Review, 6(4)368-374

Duncan, W. \& Kabare, K. (2015). The influence of corporate governance on corporate performance among manufacturing firms in Kenya: A theoretical model international journal of academic research in business and social sciences. 5(4):258-271

Geraldine, B. M., Sunday A. E., \& John, O. A. (2017). Corporate governance and organizational performance; evidence from the Nigeria Manufacturing Industry.Journal of Business and Management.19(8): 46-51

Hossein, R. D. A. \& Fatemeh, N. (2012).Analyzing the impact of corporate governance and organizational learning on strategic planning effectiveness (An empirical practice among some industrial companies in Iran).International Journal of learning and Development, 2(3): 283-293

Ingley, .C. \& Vander .N. (2005). Do Board processes influence Director and board performance? Statutory and performance implications, corporate governance.An International Review, 13(15): 632-653

Jensen, M. \& Meckling, W. (1976). "Theory of the Firm: Managerial Behavior, Agency Costs and Ownership Structure”, Journal of Financial Economics, 3(4):305-360 
Karanja, j. N (2015). Corporate Governance as A Strategic Tool toImprove Performance of Listed Companies in Kenya.Unpublished thesis, School of Business, UniversityofNairobi.

Niamh, B. (2006). Boards of Director and Firms Performances: Is there an Expectation Gap? Corporate and Governance, 14(6): 577-593

Nielsen, S., \& Huce, M. (2010). The contribution of women on Board of Directors: Going beyond the sacrifice. Corporate Governance: An International Review, 18(2): 136-148

Nwaiwu, J. N., \& Joseph, B. (2018). Core Corporate Governance Structure and Financial Performance of Manufacturing Companies in Nigeria.International Journal of Innovation Development and Policy Studies, 6(2): $35-49$

Nwiko, L. A., Florence, O. I. \& Ileko, B. G. (2018). Corporate Governance and the Performance of Manufacturing Companies in South-South Nigeria.Advance Research Journal of Multi-Disciplinary Discoveries, 26(1):36-42

Obembe, O. B, Adebisi B. A \& Adeleye O. K. (2010). Corporate Governance, Ownership Structure and Performance of Manufacturing Firms in Nigeria.Corporate Ownership and Control, 8(1): 696-706

Odiwo, W.O., Chukwuma, C.S. Kifordu, A. A. (2016). The Impact of Corporate Governance on the Performance of Manufacturing Firms in Nigeria.International Journal of Science and Research, 5(9):924-933

OECD (2010), Global Corporate Governance Forum: Background Document.

Osundina, J. A., Olayinka I. M., \& Chukwuma J. U. (2016).Corporate Governance and Financial Performance of Selected Manufacturing Companies in Nigeria.International Journal of Advanced Academic Research Social and Management Sciences, 2(10):29-43

Owolabi, S. A. (2018). Corporate Governance and Performance: A Pathological Exposition of Nigerian firms. 21 Babcock University Inaugural Lecture. April $5^{\text {th }}$

Oyedokun, G. E., Sanyaolu, W. A. \& Bamigbade, D. (2017). Corporate Governance and Financial Performance of Listed Manufacturing Firms in Nigeria.Advances in Management.16(2):3-17

Palaniappan .G. (2017). Determinant of corporate financial performance relating to board characteristics of corporate governance in indian manufacturing industry; An empirical study. European Journal of Management and Business Economics. 29(1): 67-85

Pearce, J., \& Robinson, J. (2007). Strategic Management: Formulation, Implementation Control. Journal of strategic Management, 2(4): 23-67

Pearce, J. A. \& Zahra, S. A. (1992). Board Composition from A Strategic Contingency Perspec tive. Journal of Management Studies, 29 (411-438)

Pferffer, J., \& Salancik, G. R. (1978). The External Control of Organisations: A Resource Dependence Perspective. New York : Harper \& Row.

Sathyamoorthi, C. R., Pritika, B., Mashoko, D., \& Lilian W. (2017). The Impact of Corporate Governance on Financial Performance: The Case of Listed Companies in the Consumer Services Sector in Botswana. Advances in Social Sciences Research Journal.14(22):63-77

Zeyal, A., Atif, A. \& Hazem, A. (2015). How the Corporate Governance Affects Organizational Strategy: Lessons from LOSR-Jordan Environment. Journal of Business and Management 17(1): 52-66 